\title{
SNOW CONCENTRATION AND EFFECTIVE AIR DENSITY DURING SNOW-FALLS
}

\author{
By Malcolm MelloR \\ (U.S. Army Cold Regions Research and Engineering Laboratory, Hanover, \\ New Hampshire 03755, U.S.A.)
}

\begin{abstract}
The mass concentration of falling snow $\rho_{\mathrm{s}}$ can be estimated from the snow-fall rate (accumulation rate) $q_{\mathrm{v}}$ if there is no significant wind. Limited data show only a weak relation between fall velocity $u_{\mathrm{t}}$ and $q_{\mathrm{v}}$ $\left(u_{\mathrm{t}} \approx 110 q_{\mathrm{v}}^{0.1} \mathrm{~cm} / \mathrm{s}\right.$ with $q_{\mathrm{v}}$ in $\left.\mathrm{g} / \mathrm{cm}^{2} \mathrm{~h}\right)$. Consequently there is a strong correlation $\left(r^{2}=0.97\right)$ between $\rho_{\mathrm{s}}$ and $q_{\mathrm{v}}$ $\left(\rho_{\mathrm{s}} \approx 2.57 q_{\mathrm{v}}^{0.9} \mathrm{~g} / \mathrm{m}^{3}\right.$ with $q_{\mathrm{v}}$ in $\left.\mathrm{g} / \mathrm{cm}^{2} \mathrm{~h}\right)$. A simple relation of this kind is of practical value for certain technical purposes, and more data would be welcome.
\end{abstract}

RÉsumé. Concentraîion de neige el densite efficace de l'air au cours des chutes de neige. On peut estimer la

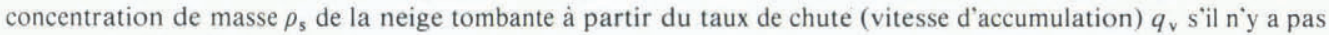
un vent significatif. Des données peu nombreuses montrent seulement une relation faible entre la vitesse de chute $u_{\mathrm{t}}$ et $q_{\mathrm{v}}\left(u_{\mathrm{t}}=110 q_{\mathrm{v}}^{0,1} \mathrm{~cm} / \mathrm{s}\right.$ avec $q_{\mathrm{v}}$ en $\left.\mathrm{g} / \mathrm{cm}^{2} \mathrm{~h}\right)$. Par conséquent il y a une forte corrélation $\left(r^{2}=0,97\right)$ entre $\rho_{\mathrm{s}}$ et $q_{\mathrm{v}}\left(\rho_{\mathrm{s}}=2,57 q_{\mathrm{v}}^{u, y} \mathrm{~g} / \mathrm{m}^{s}\right.$ avec $q_{\mathrm{v}}$ et $\left.\mathrm{g} / \mathrm{cm}^{2} \mathrm{~h}\right)$. Une simple relation de ce type a une valeur pratique pour certains usages techniques et plus d'observations seraient les bienvenues.

ZuSAMMENFASSUNG. Schneekonzentration und effektive Luftdichte bei Schneefällen. Die Massenkonzentration $\rho_{\mathrm{s}}$ fallenden Schnees kann aus der Schneefallrate (Akkumulation) $q_{\mathrm{v}}$ geschätzt werden, wenn kein starker Wind weht. Begrenzte Daten zeigen eine nur schache Relation zwischen der. Fallgeschwindigkeit $u_{\mathrm{t}}$ und $q_{\mathrm{v}}\left(u_{\mathrm{t}} \approx 110 q_{\mathrm{v}}^{0,1} \mathrm{~cm} / \mathrm{s}\right.$ mit $q_{\mathrm{v}}$ in $\left.\mathrm{g} / \mathrm{cm}^{2} \mathrm{~h}\right)$. Folglich besteht eine starke Korrelation $\left(r_{2}=0,97\right)$ zwischen $\rho_{\mathrm{s}}$ und $q_{\mathrm{v}}\left(p_{\mathrm{s}} \approx 2,57 q_{\mathrm{v}}^{0,9} \mathrm{~g} / \mathrm{m}^{3} \mathrm{mit} q_{\mathrm{v}}\right.$ in $\left.\mathrm{g} / \mathrm{cm}^{2} \mathrm{~h}\right)$. Eine einfache Beziehung dieser Art ist für gewisse technische Zwecke von praktischem Wert; mehr Datenmaterial wäre daher wünschenswert.

IN certain technical problems it is necessary to know the mass concentration of snow in the air $\rho_{\mathrm{s}}$ and the effective air density $\rho_{\mathrm{ea}}$ during periods of snow-fall. Defining $\rho_{\mathrm{s}}$ as ice mass per unit volume of snowfilled air (as is done for deposited snow):

$$
\rho_{\mathrm{ea}}=\rho_{\mathrm{a}}+\rho_{\mathrm{s}}\left(1-\rho_{\mathrm{a}} / \rho_{\mathrm{i}}\right) \approx \rho_{\mathrm{a}}+\rho_{\mathrm{s}}
$$

where $\rho_{\mathrm{i}}$ is ice density $\left(\approx 0.92 \times 10^{3} \mathrm{~kg} / \mathrm{m}^{3}\right)$ and $\rho_{\mathrm{a}}$ is the density of clear air $\left(\approx 1.3 \mathrm{~kg} / \mathrm{m}^{3}\right)$.

In calm weather, the vertical flux of snow $q_{\mathrm{v}}$ is easy to measure, e.g. by weighing the snow collected on a tray over a short time period. Representative fall velocities of snow particles $u_{t}$ are also fairly easy to measure if the complications of fall velocity variation within the dispersion are ignored. In principle, it is easy to estimate $\rho_{s}$, since

$$
\rho_{\mathrm{s}}=q_{\mathrm{v}} / u_{\mathrm{t}}
$$

However, while measurement of $q_{\mathrm{v}}$ is routine, corresponding measurements of $u_{1}$ are seldom made.

At any given location, $q_{\mathrm{v}}$ can vary by two or three orders of magnitude during a winter season (say in the range 0.002 to $2.0 \mathrm{~g} / \mathrm{cm}^{2} \mathrm{~h}$ ). By contrast, $u_{\mathrm{t}}$ is unlikely to change by more than a factor of four for the whole range of snow crystals and snow-flakes. Thus, variations in $\rho_{\mathrm{s}}$ must be controlled mainly by variations of $q_{\mathrm{v}}$.

Mellor (1966) sampled a range of snow-falls, recording $q_{\mathrm{v}}, u_{\mathrm{t}}, \rho_{\mathrm{s}}$, and characteristics of the snow crystals. If the values of $u_{\mathrm{t}}(\mathrm{cm} / \mathrm{s})$ are plotted against those of $q_{\mathrm{v}}\left(\mathrm{g} / \mathrm{cm}^{2} \mathrm{~h}\right)$, there is a weak correlation (Fig. 1) which can be described by

$$
u_{\mathrm{t}}=110 q_{\mathrm{v}}^{0.104} \text {. }
$$




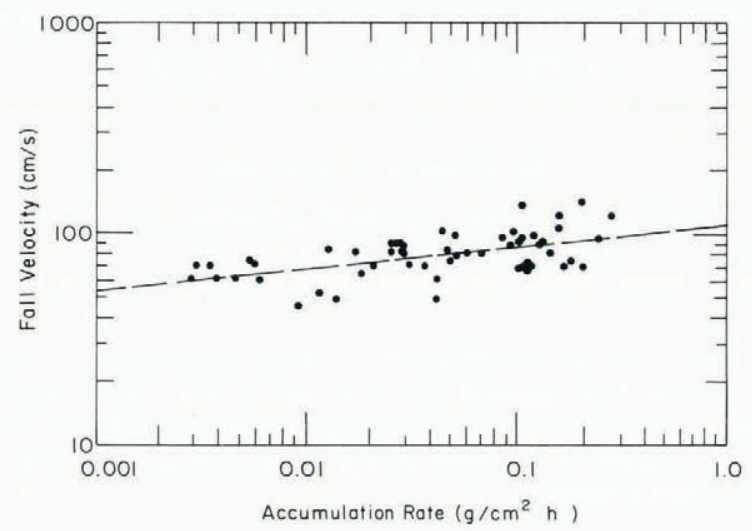

Fig. 1. Fall velocity $u_{\mathrm{t}}$ plotted against accumulation rate $q_{\mathrm{v}}$.

The coefficient of determination $r^{2}$ for the power-relation regression is 0.3 . Since $u_{\mathrm{t}}$ does not vary much, there must be a strong correlation between $\rho_{\mathrm{s}}$ and $q_{\mathrm{v}}$ (Fig. 2). The data can be described by

$$
\rho_{\mathrm{s}}=2.566 q_{\mathrm{v}}^{0.899} \approx 2.57 q_{\mathrm{v}}^{0.9} \mathrm{~g} / \mathrm{m}^{3}
$$

where $q_{\mathrm{v}}$ is in $\mathrm{g} / \mathrm{cm}^{2} \mathrm{~h}$ (which is equivalent to the accumulation rate expressed in centimetres of water per hour). The coefficient of determination $r^{2}$ is 0.969 . A result that is essentially the same as Equation (4) is obtained by substituting Equation (3) into Equation (2) and adjusting the units.

The most basic quantitative description of a snow-fall is $q_{\mathrm{v}}$. Knowing $q_{\mathrm{v}}$, an estimate of $\rho_{\mathrm{s}}$ that is sufficiently accurate for many practical purposes can be obtained from a relation such as Equation (4).

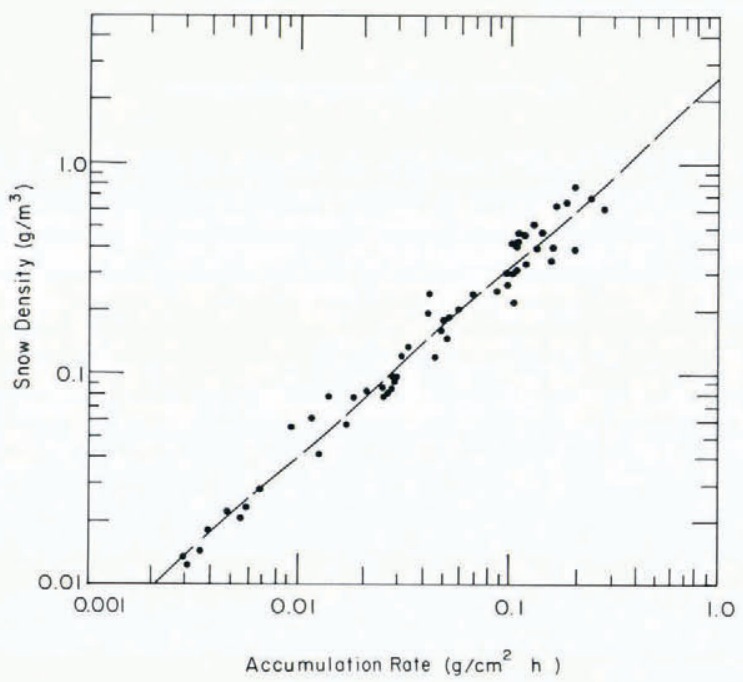

Fig. 2. Snow density $\rho_{\mathrm{s}}$ plotted against accumulation rate $q_{\mathrm{v}}$. 
This is very convenient, and so it would be useful to have more field observations of $q_{\mathrm{v}}, u_{\mathrm{t}}$, and $\rho_{\mathrm{s}}$, especially for very heavy snow-falls.

MS. received 23 November 1982

\section{REFERENCE}

Mellor, M. 1966. Light scattering and particle aggregation in snow-storms. Journal of Glaciology, Vol. 6, No. 44, p. 237-48. 